\title{
Clinical usefulness of the nested polymerase chain reaction in the diagnosis of extrapulmonary tuberculosis
}

\author{
Guadalupe García-Elorriaga, PhD, (I) Carlos Gracida-Osorno, MD,(2) Guadalupe Carrillo-Montes, MD, ${ }^{(1)}$ \\ César González-Bonilla, PhD. ${ }^{(1)}$
}

García-Elorriaga G, Gracida-Osorno C, Carrillo-Montes G, González-Bonilla C. Clinical usefulness of the nested polymerase chain reaction in the diagnosis of extrapulmonary tuberculosis. Salud Publica Mex 2009;5 I:240-245.

\begin{abstract}
Objective. To evaluate the effectiveness of nested polymerase chain reaction (PCR) for diagnosis of extrapulmonary tuberculosis (ETB), as well as the impact of PCR results on clinical management. Materials and Methods. We conducted a study of nested PCR tests in 45 patients and a review of patient hospital files, calculating sensitivity, specificity, positive predictive value (PPV), and negative predictive value (NPV). Results. PCR was positive in $51 \%$ of cases; PCR sensitivity for diagnosing TB was $86 \%$, specificity was $79 \%$, PPV was $76 \%$, and NPV was $88 \%$. When solely analyzing urine samples, sensitivity and NPV increased to $100 \%$. PCR exerted an influence on management in $27 \%$ of patients. Conclusions. PCR for rapid diagnosis of extrapulmonary TB has an adequate effect, which improves when performed on urine. The results of PCR exerted an acceptable impact on the clinical management of these patients.
\end{abstract}

Key words: tuberculosis; extrapulmonary tuberculosis; polymerase chain reaction; nested polymerase chain reaction
García-Elorriaga G, Gracida-Osorno C, Carrillo-Montes G, González-Bonilla C. Utilidad clínica de la reacción en cadena de la polimerasa anidada para el diagnóstico de tuberculosis extrapulmonar.

Salud Publica Mex 2009;5 1:240-245.

\section{Resumen}

Objetivo. Evaluar la eficacia de la reacción en cadena de la polimerasa (PCR) anidada para el diagnóstico de tuberculosis extrapulmonar, así como el impacto de sus resultados en el manejo clínico. Material y métodos. Se realizó PCR anidada en 45 pacientes y se llevó a cabo la revisión de expedientes. Se calculó sensibilidad, especificidad, valor predictivo positivo (VPP) y valor predictivo negativo (VPN). Resultados. La PCR fue positiva en $51 \%$ de los casos, la sensibilidad fue de $86 \%$, la especificidad de $79 \%$, elVPP de $76 \%$ y elVPN de $88 \%$. Al analizar solamente las muestras de orina, la sensibilidad y VPN se incrementaron a $100 \%$. La PCR influyó en el manejo de $27 \%$ de los pacientes. Conclusiones. La PCR para el diagnóstico rápido de TB extrapulmonar tiene una eficacia adecuada, la cual mejora cuando se realiza en orina. El resultado de la PCR tuvo un impacto aceptable en el manejo clínico de estos pacientes.

Palabras clave: tuberculosis; tuberculosis extrapulmonar; reacción en cadena de la polimerasa; reacción en cadena de la polimerasa anidada

(I) Unidad de Investigación Médica en Inmunología e Infectología, Hospital de Infectología, Centro Médico Nacional La Raza (CMNR), Instituto Mexicano del Seguro Social (IMSS). Mexico City, Mexico.

(2) Hospital de Especialidades, CMNR, IMSS. Mexico City, Mexico. 
$\mathrm{T}^{\mathrm{s}}$ he diagnostic approach to tuberculosis (TB) has changed little since the era of Robert Koch, whose rapid diagnostic test for TB was bacilloscopy, which is insensitive and unspecific. ${ }^{1}$ Species identification with the traditional Löwenstein-Jensen culture, considered the bacteriologic gold standard, requires 4 to12 weeks for development. Liquid culture media developed by Middlebrook (7H9 and -12) for radiometric and colorimetric systems allow for development of Mycobacterium tuberculosis (MTB) within a 2 to 3-week period, detecting small inocula such as those of 200-300 colony-forming units per $\mathrm{ml}^{2,3}$

Other TB diagnostic methods include blood cultures for extrapulmonary TB (ETB) and serologic tests by Enzyme-linked ImmunoSorbent Assay (ELISA), which do not present sufficient sensitivity and specificity to be useful and determination of adenosine deaminase. ${ }^{4,5}$

The development of DNA amplification techniques such as polymerase chain reaction (PCR) has focused the attention of investigators toward this direction. The concept of specific genetic-material amplification at detectable levels would be very attractive. The use of PCR in TB diagnosis is defined in a limited fashion; studies to date include small samples, different initiators, different diagnostic criteria, and distinct or poorly explained gold standards as well as clinical criteria, rendering comparison among these studies difficult. PCR use in the identification of MTB has exhibited excellent results, with a sensitivity that can range from 65 to $100 \%$ and a specificity of $98 \%$, in addition to the reduction of waiting days to initiate treatment (from 3 to 5 days, approximately); thus, some institutions have implemented its use as a diagnostic resource. Among the disadvantages found of PCR are its high cost (\$125 US dollars [USD]) and the need for adequate infrastructure, as well as requiring qualified personnel to perform this technique. However, no other method offers the population a rapid, sensitive and relatively accessible result. ${ }^{6-13}$

With regard to clinical usefulness, articles have been published on PCR in pulmonary TB (PTB), correlating clinical, culture and PCR data. One of the largest series was the evaluation of 844 respiratory tract samples from 421 patients over a period of six months. When carrying out a comparison with the culture, a sensitivity of $93.6 \%$ and a specificity of $97.8 \%$ were found, with a positive predictive value (PPV) of $95.5 \%$ and a negative predictive value (NPV) of 70\%. ${ }^{14}$ The usefulness of PCR has been discussed in articles and editorials, with resulting controversy concerning its application. This is due to the fact that although PCR has a high sensitivity, the presence of contamination or the inability to detect infection with live bacilli has limited its use, and that it cannot be substituted for the culture. ${ }^{15}$
ETB represents an even greater diagnostic problem than PTB because it presents with less frequency and occurs with little liberation of bacilli, as well as the fact that it is localized in sites that are difficult to access. This combination of situations gives rise to a difficulty in bacteriologic confirmation, thus implying more invasive procedures for sample obtention. ${ }^{16}$ Due to the relatively low number of cases, ${ }^{17}$ diagnosis of ETB is initially omitted and clinical signs remain undetected by the majority of clinics. ${ }^{18}$

Concerning tuberculous meningitis (TBM), this disease develops with greater frequency when a meningeal calcification or a sub-cortical focus (Rich focus) discharges its contents into the subarachnoidal space. It is known that TBM is often accompanied by miliary $\mathrm{TB}$, but the interrelationship between the development of Rich focus and miliary TB continues to be controversial. ${ }^{19,20}$ Conventional bacteriologic methods rarely detect MTB in cerebrospinal fluid (CSF) and are, thus, of limited use in TBM diagnosis; TBM's suggestive clinical characteristics are frequently supported by indirect evidence, such as CSF examination and computed tomography (CT) of the head. ${ }^{21}$

Genitourinary TB (GUTB) continues to be a serious diagnostic problem for the microbiological laboratory, because the World Health Organization (WHO) has proscribed performing bacilloscopy in urine due to its low specificity, since acid fast bacilli (AFB) are environmental saprophytes. In addition, in developing countries such as Mexico the use of the culture is unfortunately not accessible at all clinical care levels. ${ }^{22}$

Due to the previously mentioned situations, the objective of the present study was to evaluate the clinical usefulness and optimization of PCR for rapid molecular diagnosis of extrapulmonary tuberculosis.

\section{Materials and Methods}

The study was approved by the Ethics Committee at the Infectology Hospital at "La Raza" Medical Center and all participants gave written informed consent. We performed the nested PCR test on extrapulmonary samples from 45 patients from January 2001 to August 2002. We then carried out a retrospective study based on data obtained from the Clinical Microbiology Laboratory and a review of patient files. These patients were seen at the Mexican Institute of Social Security's (IMSS) La Raza Medical Center in Mexico City, a tertiary-level hospital that generally cares for patients with chronic illnesses. We reviewed clinical annotations on patients from 10 days after the request date for the PCR to analyze its impact on patient management. Similarly, we reviewed later clinical annotations to decide whether the final 
diagnosis of the case was or was not $\mathrm{TB}$, considering the treating physician's clinic as the gold standard, including treatment response. In this respect, we determined the usefulness of PCR with regard to confirmation of the clinical suspicion, diagnostic support, treatment restoration in the case of a positive test, and compatibility with the remainder of laboratory and medical office examinations. All suspected ETB patients were considered as confirmed cases (positive culture or AFB smear), highly probable cases (meeting all the clinical criteria and with all supporting evidences being positive, but having no bacterial isolation) and cases without TB.

We studied 25 samples from the cerebrospinal fluid (CSF) of patients with tuberculosis of the central nervous system (CNS) and 20 samples of urine from patients with GUTB.

Polymerase chain reaction (PCR): the mycobacterial strain utilized as a positive control was M. tuberculosis H37Rv. The DNA was isolated with guanidine isothiocyanate and phenol utilizing $500 \mu \mathrm{l}$ of the TRIzol reagent (Gibco BRL) according to the procedure described by Chomczynski. ${ }^{23}$ The specimens were also processed in the same way. The DNA was resuspended in $50 \mu 1$ of distilled water after precipitation with ethanol at $75 \%$. This solution was heated at $55^{\circ} \mathrm{C}$ for $20 \mathrm{~min}$. We determined its absorbance relationship at $260 / 280 \mathrm{~nm}$ and took 5 $\mu \mathrm{l}$ for amplification by PCR of genes coding for the 32$\mathrm{kDa}$ protein ${ }^{24}$ the MTP40 species-specific protein ${ }^{25}$ and the IS6110 sequence insertion. ${ }^{26}$ The initiator sequences employed for amplifying the species-specific gene were PT1 (5'CGG CAA CGC GCC GTC GGT GG) and PT2 (5'CCC CCC ACG GCA CCG CCG GG), with a resulting fragment of $396 \mathrm{bp} .{ }^{27}$ For IS6110 insertion-element amplification, the specific MercatoBenzoThiazole (MBT)-complex initiators were IS5 (5'CGG AGA CGG TGC GTA AGT GG) and IS6 (5'GAT GGA CCG CCA GGG CTT GC), with a 984-bp amplification fragment. The specific initiators for amplifying the gene coding for the antigen $\alpha$ of 32-kDa present in all described mycobacteria (genus-specific) were MT1 (5'TTC CTG ACC AGC GAG CTG CCG) and MT2 (5'CCC CAG TAC TCC CAG CTG TGC), with a 506-bp amplification fragment. ${ }^{28-31}$ All reactions were taken to a final volume of $50 \mu \mathrm{l}$ containing $100 \mathrm{ng}$ of purified DNA from the reference strain as well as from each clinical specimen, reaction buffer 1X, $2.5 \mathrm{U}$ of Taq polymerase, $0.2 \mathrm{mM}$ of each triphosphate deoxynucleoside, and $20 \mathrm{pM}$ of each of the three pairs of initiators. The reaction was carried out in a thermocycler (Biometra). Cycles included initial denaturation at $94^{\circ} \mathrm{C}$ for $5 \mathrm{~min}$, followed by 35 repeated denaturation cycles at $94^{\circ} \mathrm{C}$ for $1 \mathrm{~min}$, annealing at $71^{\circ} \mathrm{C}$ for $2 \mathrm{~min}$, and extension at $72^{\circ} \mathrm{C}$ for $3 \mathrm{~min}$. Subsequently, a final extension was carried out at $72{ }^{\circ} \mathrm{C}$ for $10 \mathrm{~min}$.
To increase amplification sensitivity, we performed nested PCR, amplifying an internal segment of the specific gene designed by Del Portillo; $;{ }^{27}$ internal initiators in the second PCR corresponded to nucleosides 44-65 (PT3, 5'-CAC CAC GTT AGG GAT GCA CTG C-3') and 244-265 (PT4, 5'-CTG ATG GTC TCC GAC ACG TTC G-3'), which amplified the 223-bp internal region. ${ }^{32}$ For this second step, we took $5 \mu \mathrm{l}$ of the multiplex PCR product and transferred this into $45 \mathrm{ml}$ of the pre-mixed solution containing the PCR regents at the same previously described concentration. ${ }^{24}$ Amplification was repeated for 30 cycles with the same time and temperature parameters as described previously, except for an annealing at $75^{\circ} \mathrm{C}$ for $2 \mathrm{~min}$, an extension at $72^{\circ} \mathrm{C}$ for 2 $\mathrm{min}$, and a final extension at $72{ }^{\circ} \mathrm{C}$ for $7 \mathrm{~min}$. After the $1 / 10$ amplification of the $\mathrm{PCR}$ reaction mixture, this was analyzed by electrophoresis in agarose at $1.5 \%$ containing $0.5 \mu \mathrm{g} / \mathrm{ml}$ of ethidium bromide and was visualized with an ultraviolet (UV) transilluminator.

Analysis: we calculated sensitivity, specificity, positive predictive value (PPV), and negative predictive value (NPV) according to Galen \& Gambino, ${ }^{33}$ as compared with the treating physician's clinic, including treatment response and the prevalence of TB in the studied population.

\section{Results}

With regard to patients with a presumptive diagnosis of ETB, TB of the central nervous system (CNS) was present in $25(49 \%)$, specifying cerebral affectation in five patients $(9.8 \%)$, medullar in three $(6 \%)$, meningeal in nine (18), unspecified in eight (17\%), GUTB in 20 (39\%) patients, renal-level in $19(37 \%)$, and gall bladder in one (2\%) patient (Table I).

Of these previously mentioned cases, ETB diagnosis was confirmed in $25(56 \%)$ patients by their clinical picture, including the treatment and culture, acid fast bacilli and medical office studies. Among PCR results, $23(51 \%)$ positive tests were reported. The clinic considered that the PCR result supported the final diagnosis (whether positive or negative) in 41 (91\%) patients. PCR sensitivity for diagnosing ETB was $86 \%$, specificity was $79 \%$, PPV was 76\%, and NPV, $88 \%$ (Table II).

Confirmatory studies were requested in 44 (98\%) patients; positive bacilloscopy and culture were found in sixteen (36\%) patients and a positive radiologic study finding was observed in $30(67 \%)$ patients. PCR resultbased treatment was initiated in twelve $(27 \%)$ patients (Table III).

To evaluate clinical usefulness, we documented the PCR result and the treating physician's final decision 
Table I

Affected site localization in patients With PRESUMPTIVE DIAGNOSIS OF TUBERCULOSIS. INVESTIGATION UNIT IN IMMUNOLOGY AND INFECTOLOGY, LA RAZA Medical Center, Mexico. 2001-2002

\begin{tabular}{lc} 
Localization & No. of patients $(\mathrm{n})(\%)$ \\
CNS & $25(100)$ \\
\hline Meningeal & $9(36)$ \\
\hline Cerebral & $5(20)$ \\
\hline Medullar & $3(12)$ \\
\hline NS* & $8(32)$ \\
GUTB & $20(100)$ \\
\hline Renal & $19(95)$ \\
\hline Bladder & I (5) \\
$*$ NS: not specified; CNS: Central nervous system; GUTB: Genitourinary \\
tuberculosis
\end{tabular}

Table II

Polymerase chain Reaction in patients WITH EXTRAPULMONARY TUBERCULOSIS. INVESTIGATION

UNIT IN IMMUNOLOGY AND INFECTOLOGY, LA RAZA Medical Center, Mexico. 200I-2002

Positive PCR $23(5 \mathrm{I})$ Support for final diagnosis (positive or negative) 4I (9I) Sensitivity $(86)$

Specificity

(79)

PPV

(76)

NPV

n: number of cases

PCR: polymerase chain reaction

TBE: extrapulmonary tuberculosis

PPV: positive predictive value

$\mathrm{NPV}$ : negative predictive value

for initiating treatment, as well as the result obtained case-by-case. Of the 25 patients with presumptive diagnosis of TB in CNS, only 14 were finally considered as positive for TB; of these, nine (68\%) presented positive results with PCR and treatment was initiated based on these results in four (29\%) patients. Nonetheless, in five $(38 \%)$ cases with high clinical suspicion, treatment was initiated despite negative results by PCR. Finally,
TB diagnosis was discarded in 11 patients, nine (82\%) of whom had negative results by PCR, with treatment modification based on these results in five $(45 \%)$. One $(9 \%)$ false positive result was reported in which the patient had a diagnosis of HIV and Hodgkin lymphoma (Table IV).

Regarding PCR test in urine, we analyzed 20 cases; of these, nine were finally considered as positive for TB and all presented positive results by PCR, with three

Table III

ComplementaRY StUdies ReQuested.

InVESTIGATION UNIT IN IMMUNOLOGY AND INFECTOLOGY, La Raza Medical Center. Mexico, 200 I-2002

n (\%)

Confirmatory studies $44(98)$

Bacilloscopy and positive cultures $16(36)$

Radiology $30(67)$

PCR-associated treatment initiation $12(27)$

PCR: polymerase chain reaction

Table IV

Polymerase chain ReAction Results for tUberculosis OF THE CENTRAL NERVOUS SYSTEM AND GENITOURINARY TUBERCULOSIS. INVESTIGATION UNIT IN IMMUNOLOGY and Infectology, La Raza Medical Center. MeXICo, 200I-2002

$$
\begin{gathered}
\text { TB in } \\
\text { CNS GUTB } \\
n(\%) n(\%)
\end{gathered}
$$

\begin{tabular}{lrr} 
With TB and positive PCR & $9 / 14(68)$ & $9 / 9(100)$ \\
\hline PCR-associated treatment initiation & $4(29)$ & $3(33)$ \\
Without TB and negative PCR & $9 / 11(82)$ & 0 \\
\hline Modification of treatment & $5(45)$ & $6(54)$ \\
Sensitivity & $(64)$ & $(100)$ \\
\hline Specificity & $(82)$ & $(82)$ \\
\hline PPV & $(82)$ & $(82)$ \\
\hline NPV & $(64)$ & $(100)$
\end{tabular}

TB: tuberculosis

CNS: central nervous system GUTB: genitourinary system PPV: positive predictive value $\mathrm{NPV}$ : negative predictive value 
(33\%) initiating treatment based on this result. In cases considered negative, initial treatment was modified based on the PCR result in six (54\%) patients. Two false positives occurred due to presenting negative cultures and these patients were found to be asymptomatic (Table IV).

Six patients presented a positive culture in CSF and only two in urine. The patients' evolution with presumptive diagnosis but without bacteriologic confirmation was clinically toward tuberculous disease.

For renal TB, abdominal radiographs, intravenous urography, retrograde pyelography and computed tomography (CT) demonstrated various patterns of calcifications, including amorphous, granular and lobar patterns.

\section{Discussion}

The clinical presentation of ETB is frequently atypical; tissue samples for confirmation of the diagnosis can be difficult to obtain on some occasions, and conventional diagnostic methods possess low sensitivity. The availability of $\mathrm{CT}$, magnetic resonance (MR), and endoscopy aid greatly in anatomic localization. ${ }^{34}$

Our study coincided with the literature, finding only $36 \%$ of cases of ETB with a positive culture. This information is useful retrospectively because several weeks are necessary for the culture to develop. ${ }^{35}$ In the present study, PCR exhibited greater sensitivity than microscopy and the culture, and could facilitate therapeutic decisions for patients with a clinical suspicion of ETB; as was found by other authors. ${ }^{36-38}$

For diagnosis of GUTB, although a high index for clinical suspicion is necessary, ${ }^{39}$ PCR can be useful for cases in which bacteriologic and clinical diagnoses of TB are not conclusive..$^{40}$ We found PCR to be a very rapid diagnostic method for GUTB. It was sensitive, specific, and prevented waiting to initiate treatment because the sensitivity, specificity, PPV, and NPV for ETB were 76, 84,82 , and $78 \%$, respectively; on analyzing only urine samples sensitivity and NPV rose to $100 \%$.

In our study, nested PCR dramatically increased sensitivity and specificity of DNA amplification over the conventional single-step PCR, in that initial multiplex PCR did not detect any sample as positive. The fact that amplification by nested PCR improves sensitivity and specificity renders it necessary for rapid diagnosis of ETB in the clinical laboratory. ${ }^{41,42}$

In Mexico, there are very few studies that have detected the usefulness of PCR in ETB. Our data are in agreement with some, ${ }^{43}, 44$ while a discrepancy exists with another. ${ }^{45}$
Rapid molecular diagnostic tests for PTB influences decisions concerning the initiation of antituberculosis therapy (antiTB) depending on the clinical suspicion. This includes patients for whom bacilloscopy is positive but clinical suspicion is intermediate or low, and patients for whom bacilloscopy is negative but clinical suspicion of PTB is high or intermediate.

Nevertheless, in the area in which clinical data are most scarce -molecular diagnosis in non-respiratory samples such as sterile body fluids (especially urine, CSF, and pleural fluids), and gastric and tissue aspirates including formalin-fixed samples- participation is required by multiple institutions to carry out an optimal clinical study design to evaluate PCR in extrapulmonary samples. Protocols should be developed to standardize sample processing with a sufficient number of protocols at each site to obtain an adequate quantity of positive results and to be able to validate these. ${ }^{46,47}$

In conclusion, even though this is a preliminary study, our results permitted us to claim the usefulness of this fast and reliable diagnostic procedure as an important tool against TB when used together with the clinical data available. Rapid molecular diagnosis of ETB in our environment possesses adequate efficiency, which improves when it is carried out in urine. The PCR result exerted an acceptable impact on the clinical management of these patients. At present we are evaluating a larger number of clinical samples, comparing these with cultures such as the gold standard.

\section{References}

I. Murray PR, Rosenthal KS, Kobayashi GS. Medical Microbiology. 5th ed. Philadelphia (PA): Elsevier- Mosby, 2005.

2. Middlebrook G, Riggiardo Z,Tiggertt W.Automatable radiometric detection of growth of M. tuberculosis in selective media.Am Rev Resp Dis 1977; I15:1066.

3.Anargyros P,Astill DS, Lim IS. Comparison of improved BACTEC and L-J media for culture of Mycobacteria from clinical specimens.J Clin Microbiol 1990;28:1288-1291.

4. Kaneko K, Onodera O, Miyatake T,Tsuji S. Rapid diagnosis of tuberculous meningitis by polymerase chain reaction (PCR). Neurology 1990;40:1617-1618

5. Bhigjee Al, Padayachee R, Paruk H, Hallwirth-Pillay KD, Marais S, Connoly C. Diagnosis of tuberculous meningitis: clinical and laboratory parameters. Int J Infect Dis 2007; I : 348-354.

6. Desaid D, Nataraj G, Kulkarni S, Bichile L, Mehta P, Baveja S, et al. Utility of the polymerase chain reaction in the diagnosis of tuberculous meningitis. Res Microbiol 2006; 157(10):967-970.

7. Gopi A, Madhavan SM, Sharma SK, Sahn SA. Diagnosis and treatment of tuberculous pleural effusion in 2006. Chest 2007;131:880.

8. Caws M,Wilson SM, Clough C, Drobniewski F. Role of IS6II0-targeted PCR, culture, biochemical, clinical, and immunological criteria for diagnosis of tuberculous meningitis. J Clin Microbiol 2000;38:3I50-3I55. 
9. Juan RS, Sánchez-Suárez C, Rebollo MJ, Folgueira D, Palenque E, Ortuño $B$, et al. Interferon gamma quantification in cerebrospinal fluid compared with PCR for the diagnosis of tuberculous meningitis. J Neurol 2006;253(I0):1323-1330.

10. Neggi SS,Anand R, Pasha ST, Gupta S, Basir SF, Khare S, et al. Diagnostic potential of IS6II0, 38kDa, 65kDa and $85 \mathrm{~B}$ sequence-based polymerase chain reaction in the diagnosis of Mycobacterium tuberculosis in clinical samples. Indian J Med Microbiol 2007;25:43.

II. Rafi W,Venkataswamy MM, Ravi V, Chandramuki A. Rapid diagnosis of tuberculous meningitis: A comparative evaluation of in-house PCR assays involving three mycobacterial DNA sequences, IS6II0, MPB-64 and 65 kDa antigen.J Neurol Sci 2007;252:163-I68.

12. Rafi W, Venkataswamy MM, Nagarathna S, Satischandra P, Chandramuki A. Role of IS6I I 0 uniplex PCR in the diagnosis of tuberculous meningitis: experience at a tertiary neurocentre. Int J Tuberc Lung Dis 2007; I :209-2 I 4. 13. Chakravorty S, Sen MK, Tyagy JS. Diagnosis of extrapulmonary tuberculosis by smear, culture, and PCR using universal sample processing technology.J Clin Microbiol 2005;43:4357-4362.

14. Stephen P, Sharon L, Catanzaro A. Clinical efficacy of amplified $M$. tuberculosis direct test for the diagnosis of pulmonary tuberculosis. Am J Respir Crit Care Med 1996;153:1606-1610.

15. Barnes P. Rapid diagnostic test of tuberculosis: progress but no gold standard.Am J Respir Crit Care Med 1997;155:1497-1498.

16.American Thoracic Society. Diagnostic standards and classification of tuberculosis in adults and children. Am J Respir Crit Care Med 2000;161:1376-1395.

17. Centers for Disease Control and Prevention: Reported Tuberculosis in the United States. 1997.Atlanta (GA): Centers for Disease Control and Prevention, 1998.

18. Ozkutuk A, Kirdar S, Ozden S, Esen N. Evaluation of Cobas Amplicor MTB test to detect Mycobacterium tuberculosis in pulmonary and extrapulmonary specimens. New Microbiol 2006;29:269-273.

19. Delgado-Morales M, Chávez-Macías LG, Olvera-Rabiela JE, LópezLuna J, Carrera-González E, Manrique-Ortega J. Algunos datos de la neurotuberculosis obtenidos de la revisión de 13689 autopsias. Patologia 1992;30:139-143.

20. Donald PR, Schaaf HS, Schoeman JF. Tuberculous meningitis and miliary tuberculosis: the Rich focus revisited.J Infect 2005:50:193-195.

2I. Seth P,Ahuja GK, Bhanu NV, Behari M, Bhowmik S, Broor S, et al. Evaluation of polymerase chain reaction for rapid diagnosis of clinically suspected tuberculous meningitis. Tuber Lung Dis 1996;77: 353-357. 22. Norma Oficial Mexicana. NOM-006-SSA2-1993. Para la prevención y control de la tuberculosis en la atención primaria a la salud. Mexico: Secretary of Health, 1993.

23. Chomczynski P.A reagent for the single-step simultaneous isolation of RNA, DNA and proteins from cell and tissue samples. Biotechniques 1993; 15:532-537.

24. Borremans, M, de Wit L,Volckaert G, Ooms J, de Bruyn J, Huygen $K$, van Vooren JP, Stelandre M, Verhofstadt R, Content J, et al. Cloning, sequence determination, and expression of a 32-kilodalton-protein gene of Mycobacterium tuberculosis. Infect Immun 1989;57:3 I23-3 I30. 25. Parra CA, Londoño LP, Del Portillo P, Patarroyo ME. Isolation, characterization, and molecular cloning of a specific Mycobacterium tuberculosis antigen gene: identification of a species-specific sequence. Infect Immun 199|;59:34| I-34 I7.

26. Thierry D, Brisson-Noel A,Vincent-Levy-Frebault V, Nguyen S, Guesdon JL, Gicquel B. Characterization of a Mycobacterium tuberculosis insertion sequence, IS6I I 0 , and its application in diagnosis.J Clin Microbiol 1990;28:2668-2673.

27. Del Portillo P, Murillo LA, Patarroyo ME.Amplification of a speciesspecific DNA fragment of Mycobacterium tuberculosis and its possible use in diagnosis. J Clin Microbiol 1991;29:2163-2168.
28. Kitaura H, Ohara N, Matsuo T, Tasaka H, Kobayashi K, Yamada T. Cloning, sequencing and expression of the gene for alpha antigen from Mycobacterium intracellulare and use of PCR for the rapid identification of Mycobacterium intracellulare. Biochem Biophys Res Commun 1993;196:1466-1473.

29. Matsuo K, Yamaguchi R, Yamazaki A, Tasaka H, Terasaka K, Yamada T. Cloning and expression of the gene for the cross-reactive alpha antigen of Mycobacterium kansasii. Infect Immun 1990;58:550-556.

30. Matsuo K, Yamaguchi R, Yamazaki A, Tasaka H,Yamada T. Cloning and expression of the Mycobacterium bovis BCG gene for extracellular alpha antigen.J Bacteriol 1988; 170:3847-3854.

3I. Ohara N, Matsuo K, Yamaguchi R, Yamazaki A, Tasaka H, Yamada T.

Cloning and sequencing of the gene for alpha antigen from Mycobacterium avium and mapping of B-cell epitopes. Infect Immun 1993;61: I I73-I 179. 32. Gori A, Franzetti F, Marchetti G, Catozzi L, Corbellino M. Specific detection of Mycobacterium tuberculosis by mtp40 nested PCR.J Clin Microbiol 1996;34:2866-2867.

33. Galen RS, Gambino RS. Beyond normality: the predictive value and efficiency of medical diagnosis. New York (NY): John Wiley and Sons, 1975. 34. Sharma SK, Mohan A. Extrapulmonary tuberculosis. Indian J Med Res 2004; 120:316-353.

35. Folgueira L, Delgado R, Palenque E, Noriega AR. Polymerase chain reaction for rapid diagnosis of tuberculous meningitis in AIDS patients. Neurology 1994;44: 1336-1338.

36. Nguyen LN, Kox LF, Pham LD, Kuijper S, Kolk AH.The potential contribution of the polymerase chain reaction to the diagnosis of tuberculous meningitis. Arch Neurol 1996;53:771-776.

37. Kolk AH, Kox LF, van Leeuwen J, Kuijper S, Hansen HM. Clinical utility of the polymerase chain reaction in the diagnosis of extrapulmonary tuberculosis. Eur Resp J 1998; I I(6): I222-1226.

38. Conaty SJ, Claxton AP, Enoch DA, Hayward AC, Lipman MC, Gillespie $\mathrm{SH}$. The interpretation of nucleic acid amplification tests for tuberculosis: do rapid tests change treatment decisions? J Infect 2005;50:187-192. 39. Hemal AK, Gupta NP, Rajeev TP, Kumar R, Dar L, Seth P. Polymerase chain reaction in clinically suspected genitourinary tuberculosis: comparison with intravenous urography, bladder biopsy, and urine acid fast bacilli. Urology 2000;56:570-574.

40. Torrea G, van de Perre P, Ouedraogo M, Zouqba A, Sawadogo A, Dinqtoumda B, et al. PCR-based detection of the M. tuberculosis complex in urine of HIV-infected and uninfected pulmonary and extrapulmonary tuberculosis patients in Burkina Faso.J Med Microbiol 2005;54(Pt I):39-44. 4I. Nakajima H, Hatamura T, Ikemoto T, Ueda K, Nakagawa T, Shimizu A. Evaluation of the polymerase chain reaction for diagnosis of tuberculous meningitis. Rinsho Byori 1995;43:843-846.

42. Takahashi T, Nakayama T, Tamura M, Ogawa K, Tsuda H, Morita A. Nested polymerase chain reaction for assessing the clinical course of tuberculous meningitis. Neurology 2005;64:1789-1793.

43. Portillo-Gómez L, Morris SL, Panduro A. Rapid and efficient detection of extra-pulmonary M. tuberculosis by PCR analysis. Int J Tuberc Lung Dis 2000;4:361-370.

44. Moguel-Morán MC, Hernández DA, Peña Montes de Oca PM, Gallegos-Arreola MP, Flores-Martínez SE. Detection of M. tuberculosis by polymerase chain reaction in a selected population in northwestern Mexico. Rev Panam Salud Publica 2000;7:389-394.

45. Kato-Maeda M, Bobadilla-del Valle M, Martínez-Gamboa A, HernándezCruz A, Ramírez-Mora I, Cerón-Enríquez N, et al. Eficacia e impacto de la prueba de la reacción en cadena de la polimerasa en el diagnóstico de tuberculosis extrapulmonar. Rev Invest Clin 2002;54:509-5I4. 46. Wise GJ, Shteynshiyuger A. An update on lower urinary tract tuberculosis. Curr Urol Rep 2008;9:305-313.

47. Rahman ML, Basher A, Rashid M, Islam M, Kuddus R, Arif SM, et al. Central nervous system tuberculosis and adjuvant corticosteroid therapy. Mymensingh Med J 2009; 18:47-5I. 